\title{
Thermal and Environmental Analysis Solar Water Heater System for Residential Buildings
}

\author{
Reza Alayi $\mathbb{D}^{1}{ }^{1}$ Nima Khalilpoor $\mathbb{D}^{2},{ }^{2}$ Saeid Heshmati, ${ }^{3}$ Atabak Najafi $\mathbb{D}^{4}{ }^{4}$ \\ and Alibek Issakhov ${ }^{5}$ \\ ${ }^{1}$ Department of Mechanics, Germi Branch, Islamic Azad University, Germi 5651763764, Iran \\ ${ }^{2}$ Department of Energy Engineering, Graduate School of the Environment and Energy, Science and Research Branch, \\ Islamic Azad University, Tehran, Iran \\ ${ }^{3}$ Department of Mechanics, Energy Institute of Higher Education, Saveh 3917767746, Iran \\ ${ }^{4}$ Department of Electrical Engineering, Eskisehir Osmangazi University, Eskisehir, Turkey \\ ${ }^{5}$ Faculty of Mechanics and Mathematics, Department of Mathematical and Computer Modelling, Al-Farabi Kazakh \\ National University, Almaty, Kazakhstan
}

Correspondence should be addressed to Reza Alayi; reza.alayi@yahoo.com and Nima Khalilpoor; nimakhalilpoor@gmail.com

Received 10 April 2021; Revised 4 July 2021; Accepted 24 July 2021; Published 14 August 2021

Academic Editor: Ángel Antonio Bayod-Rújula

Copyright (c) 2021 Reza Alayi et al. This is an open access article distributed under the Creative Commons Attribution License, which permits unrestricted use, distribution, and reproduction in any medium, provided the original work is properly cited.

\begin{abstract}
Due to the reduction of fossil resources, the replacement of renewable energy sources such as solar energy has become mandatory. Solar energy does not contain pollution and widely available in all parts of the world, especially in warm regions. Our country (IRAN) is geographically located in a hot and dry region, and with more than 280 sunny days per year, one of the nonpower applications of solar energy is heating space and water consumption of the building using solar thermal energy. Solar water heaters can be used to heat the water used in buildings, which is the main purpose of this study. Water heating consumes an average of $20 \%$ to $30 \%$ of the total energy consumption in the residential building. Therefore, using solar water heaters annually can provide $70 \%$ of the energy needed for water heating. The system designed in this research is able to provide $75 \%$ of the hot water consumption needs. If an auxiliary heat source is used next to this system, all hot water needs of the building can be met throughout the year. In this case, as much as $237.3 \mathrm{kWh}$, energy will be saved from fossil energy sources.
\end{abstract}

\section{Introduction}

The annual energy consumption of the world currently is around $500 \mathrm{EJ}$ [https://www.iea.org/]. This amount of energy is equal to $16 \mathrm{TW}$ power. The contribution of each energy source in providing this amount of energy is shown in Figure 1.

As can be seen, $34.3 \%$ of this energy is supplied by oil, $25.1 \%$ by coal, $20.9 \%$ by natural gas, $13.2 \%$ by renewable energy, and $6.5 \%$ by nuclear energy. The annual electricity consumption in the world is about $18000 \mathrm{TWh}$, which is equivalent to 2 TW power [1-3]. As shown in Figure 2, this amount of electricity is generated from a variety of sources. Electricity generated by coil is $39.8 \%$, by natural gas is $19.6 \%$, renewable energy is $17.9 \%$, nuclear energy is $15.7 \%$, and by oil is $6.7 \%$. Renewable resources account for $17.9 \%$ of total electricity generation, $16.1 \%$ related to large hydropower plants, $1 \%$ related to biomass, and $0.8 \%$ related to other renewable energy sources.

The world is very difficult to exactly determine; how long fossil fuels will be available. Recent reports indicate that oil and gas resources will be sufficient for another 30 and 60 years to meet current needs, respectively $[4,5]$. All of fossil fuels, when burned, produce carbon dioxide. Releasing large amounts of this gas into the atmosphere warms the earth by creating a greenhouse effect [6-8]. Research shows that the amount of carbon dioxide in the atmosphere over the past few thousand years and until the beginning of the industrial revolution in the early nineteenth century had an almost constant value of $280 \mathrm{ppm}$. The amount of atmospheric $\mathrm{CO}_{2}$ 


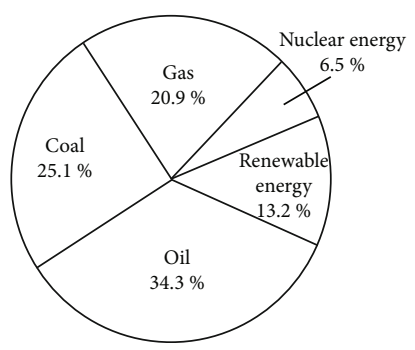

FIGURE 1: Contribution of each energy source to supply the primary energy in the world.

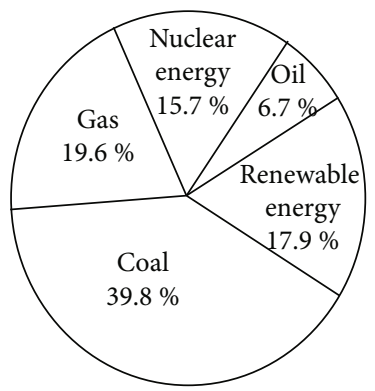

Figure 2: Generate electricity from various sources.

initially increased slowly due to the burning of coal, but after world war second, due to the wider use of fossil fuels, the amount of $\mathrm{CO}_{2}$ in the atmosphere has accelerated. As a result of these changes, since 1900 until now, the earth has warmed up to $0.7^{\circ} \mathrm{C}$, which has brought the earth's temperature to its highest level in 12,000 years. Figure 3 shows the changes of average temperature of the earth between 1980 and 2017 years [9].

Figure 4 shows the high capacity of solar energy. Solar radiation on earth is 14,000 times greater than the world's energy consumption. The sun's radiant energy, which reaches the earth in just one year, is known to be far greater than all fossil and nuclear fuel sources. According to Figure 4, despite having great potential, solar energy has a small share in energy production. So it seems necessary to study the production of solar energy as renewable energy. Solar energy is free of pollution and is widely available in all parts of the world, especially in warm regions and in areas far from the global electricity grid, used to generate electricity, heating, and economic cooling [9-12]. Our country (Iran) is geographically located in a hot and dry region and with more than 280 sunny days per year, and its annual solar radiation is estimated at $2200-1800 \mathrm{kWh} / \mathrm{m}^{2}$, which is higher than the global average. The loss of electricity generation, transmission, and distribution and the dispersion of the country's population make economical the use of solar energy [13].

In these countries, the development of solar energy technology has played an important role in meeting energy needs. Increasing energy efficiency in energy equipment and processes in buildings can be done by taking various measures. Since the measures related to energy efficiency are often faced with limited financial resources, it is important to study the set of possible measures and their economic and technical prioritization. One of the researchers who worked on the thermal performance solar heat water system was Kalogirou [14], Zhao et al. [15], Koroneos and Nanaki [16], and Tanha et al. [17]. One of the researchers who worked on the solar heat water system for residential buildings was Shi et al. [18], Dharuman et al. [19], Fan et al. [20], Cao et al. [21], Chow et al. [22], and Alayi et al. [23]. Research has been done in this area: Madani et al. [24] have provided research titled heating solutions for residential buildings in China: current status and future outlook. Souliotis et al. [25] present the solar water heating for social housing: energy analysis and life cycle assessment. Fani and Sadreddin [26] present solarassisted CCHP system, energetic, economic, and environmental analysis, case study: educational office buildings. Altoé et al. [27] have provided research titled an analysis of the economic viability and greenhouse gas emissions reductions resulting from the use of solar water heaters in a typical Brazilian dwelling. Hossain et al. [28] have provided research titled thermal and economic analysis of low-cost modified flat-plate solar water heater with parallel two-side serpentine flow. Şerban et al. [29] have provided research titled economic and environmental analysis of investing in solar water heating systems.

Bouhal et al. [30] have provided research titled design and thermal performance optimization of a forced collective solar hot water production system in Morocco for energy saving in residential buildings. Ayadi and Al-Dahidi [31] have provided research titled comparison of solar thermal and solar electric space heating and cooling systems for buildings in different climatic regions. Alayi et al. [32] have provided research titled thermal analysis of parabolic trough concentration photovoltaic/thermal system for using in buildings.

In this research, technical and energetic analyses of the use of solar energy in the preparation of water heaters for residential buildings using a solar water heater are presented. To produce the required hot water and heat the fluid, a solar collector is used. Thermal energy from the solar collector is stored in a spare storage tank. The system is simulated by TRNSYS and $T^{*}$ sol software. The purpose of this study is to generate the thermal energy required by the building with a view to achieving maximum solar energy. After achieving this goal, the amount of thermal energy production as well as nonemission of environmental pollutants has been determined.

\section{Materials and Methods}

2.1. Climatic Conditions. The amount of solar energy received in different places varies depending on the difference in latitude, altitude, atmospheric phenomena, etc. Therefore, in order to obtain information about radiation, the latitude and longitude of that place must be determined, so that the monthly and annual average radiation received from the sun can be determined at the horizon level and all levels with different directions and slopes for the desired location. In this study, the city of Tehran has been studied as a case study due to the fact that the central cities of Iran have a high intensity 


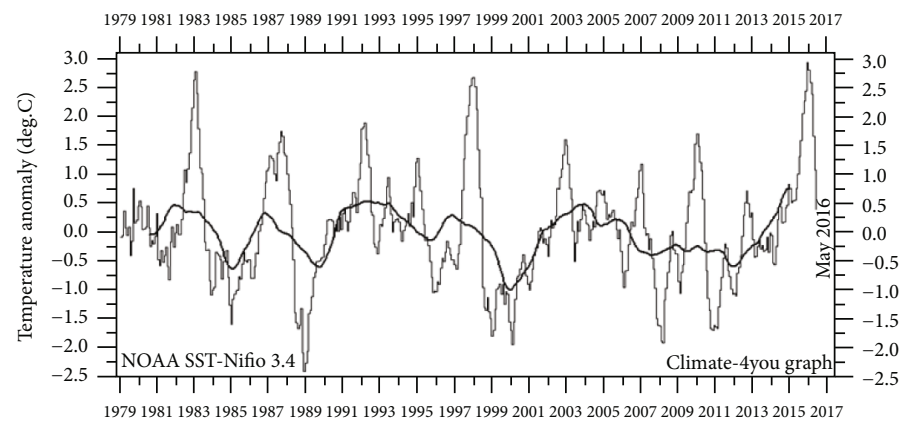

Figure 3: Changes of Earth's average temperature between 1980 and 2017 years.

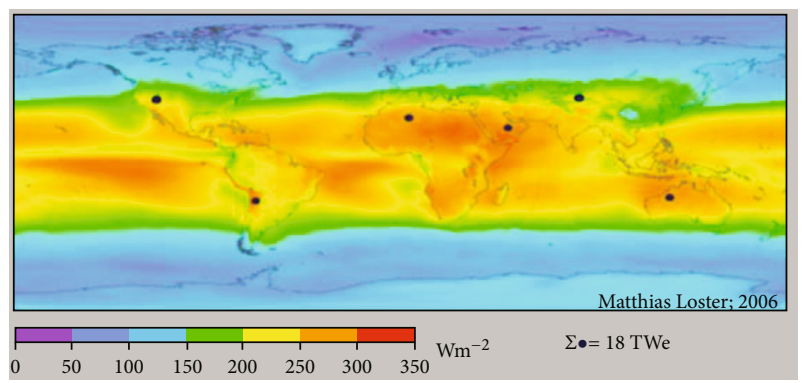

FIGURE 4: High capacity of solar energy [https://helioscsp.com].

of solar radiation $\left(4.5-5.2 \mathrm{kWh} / \mathrm{m}^{2} /\right.$ day) and the use of these systems has a better justification.

The city of Tehran has a latitude of $35.4^{\circ}$, a longitude of $51.3^{\circ}$, altitude of $1990 \mathrm{~m}$ above sea level, and an average temperature of $18^{\circ} \mathrm{C}$. Also, the average wind speed in Tehran is $2.7 \mathrm{~m} / \mathrm{s}$. As the input of the problem, accurate geographic information such as the amount of sunlight and average temperature is required in different months of the year. Figure 5 shows the annual intensity of solar radiation in Tehran, and Figure 6 shows the average temperature in different months of the year.

As can be seen in the figures, the city of Tehran has the maximum and minimum average temperatures of 40 and $-5^{\circ} \mathrm{C}$, which are related to the months of July and January, respectively. Figure 6 also shows that the city of Tehran has an average annual radiation intensity of $153.6 \mathrm{~kW} / \mathrm{m}^{2}$. Figure 7 shows the annual humidity rate for the city of Tehran during the months of the year.

2.2. Schematic and Simulation of the Studied System. A solar water heater is a device that converts solar energy (direct and indirect light) into thermal energy and transfers it to water. The solar water heaters can be classified based on their differences in the type of solar energy absorber collector, which are solar water heaters with flat collectors and with vacuum tubular collectors. The schematic of the design system for supplying the hot water consumption in the studied residential building is shown in Figure 8. As can be seen, the solar water heater system has the following components:

(i) Absorbent Surface (Collector). In this study, the flat plate collector type has been selected and its number is determined based on the daily consumption of hot water. In general, the collectors used in solar water heaters are in two types of plate and tube, which flat plate is more commonly used in collectors. These types of collectors are used when the climate of the region is not cold and is more efficient

(ii) Spare Storage Tank. This tank is usually in the form of a double-walled tank or a coiled tank

(iii) Circulation Pump. Used to circulate water inside collectors and heat exchange with tank

(iv) Expansion Source. Used to prevent volume fluctuations and smooth fluid pressure

TRNSYS software is used for the technical simulation of the studied system. Figure 8 shows the designed solar water heater system in TRNSYS software.

According to the existing standards in the field of hot water consumption in Iran, 60 liters of hot water is considered per person per day. For a family of 4 people, the volume of hot water consumed is about 240 lit/day [33]. Estimation of the energy required for this amount of water according to the inlet and outlet water temperature is the main and basic step of the present research, which will be discussed below. The temperature required to supply hot water is calculated by the following equation:

$$
Q=C_{P} \cdot M \cdot\left(T_{2}-T_{1}\right)
$$

where $M$ is the actual amount of hot water consumed per day in liters, $C_{P}$ is the specific gravity of water at constant pressure in terms of $\mathrm{kJ} / \mathrm{kg} . \mathrm{K}$, and $T_{1}$ and $T_{2}$ are the inlet and outlet water temperatures in degrees Celsius, respectively. The values of these parameters are given in Table 1 .

According to the data in Table 1, it can be said that the equivalent heat or $4526 / 24 \mathrm{kWh}$ is needed annually to supply the hot water consumption of this residential building. If $75 \%$ of this energy is supplied by the solar system, the total amount of energy from the solar water heater system for a family of four people will be equal to $3395 \mathrm{kWh}$. Table 2 shows the specifications of the components of the solar water heater system. 


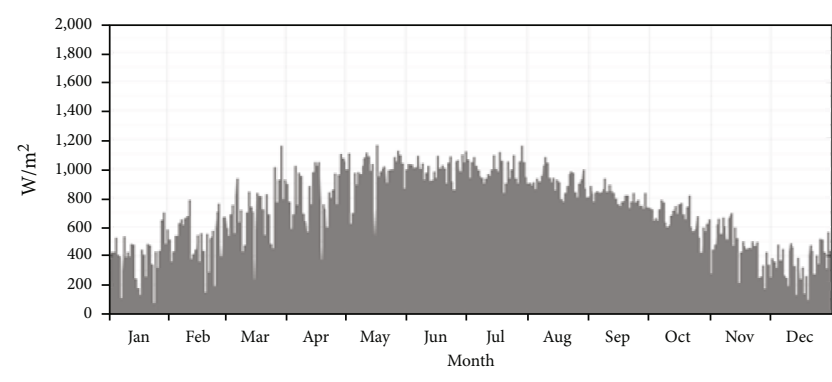

Figure 5: Annual solar radiation intensity in Tehran [http://www .tehranmet.ir/].

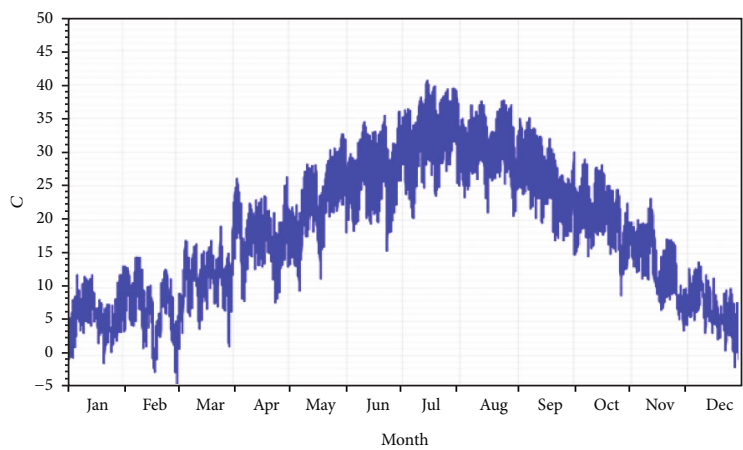

Figure 6: The average temperature of Tehran in different months of the year [http://www.tehranmet.ir/].

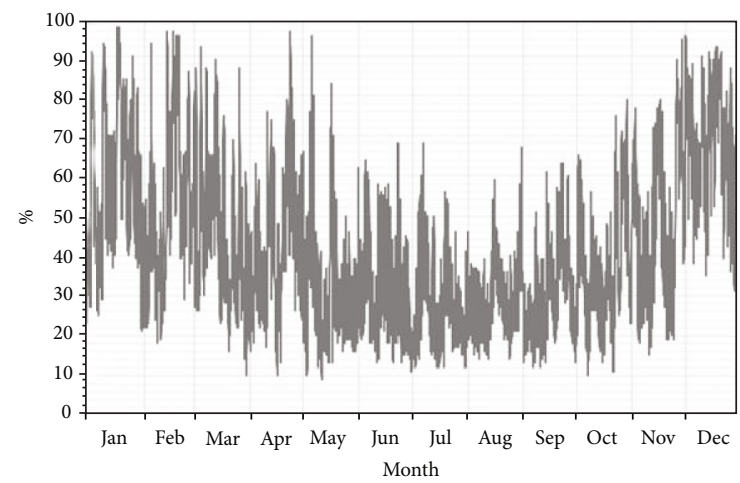

FIgURE 7: Annual humidity rate for Tehran during the months of the year [http://www.tehranmet.ir/].

\section{Results}

TRNSYS software is used to technically analyze the solar water heater system. Figures 9 and 10 show the thermal energy and temperature of the hot water generated by the solar water heater system.

It is clear from Figures 9 that the highest thermal energy produced by the solar water heater system is about $3900 \mathrm{~kJ} / \mathrm{h}$ and the highest output temperature of this system is about 98 ${ }^{\circ} \mathrm{C}$. Figure 10 shows the inlet and outlet temperatures of collector.

As shown in Figure 10, according to the production temperature of the studied system, the amount of thermal energy produced by this system is $3326.3 \mathrm{kWh} / \mathrm{yr}$, which is almost equal to the required heat load to supply the building's hot

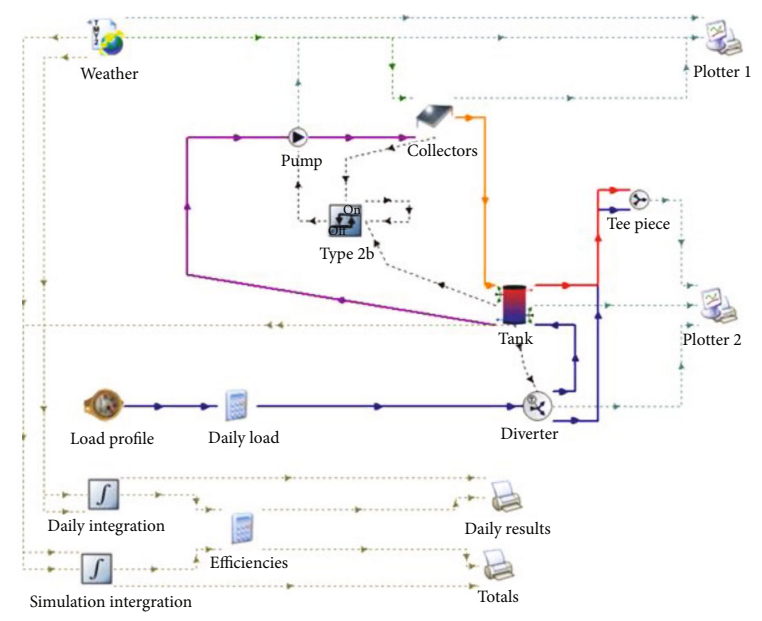

FIGURE 8: Designed solar water heater system in TRNSYS software.

water. Figure 11 shows the inlet and outlet temperature of solar collector heating system.

It can be seen that the temperature difference between the inlet and outlet is very high on some days. In order to further analyze the solar water heater system, we will consider a specific day of the year and examine the system's outputs. To do this, we consider June 18 , in which the intensity of solar radiation is equal to $7.36 \mathrm{~kW} / \mathrm{m}^{2}$. According to Figure 11 , the maximum temperature produced by the collector is $142^{\circ} \mathrm{C}$, and considering that the maximum required temperature of the study building is $60^{\circ} \mathrm{C}$, then, this system has the ability to provide the required temperature. Figures 12 and 13 show the output thermal energy and the hot power temperature of the system, respectively.

Figure 12 shows that the total thermal energy obtained from the designed solar water heater system is equal to $8.87 \mathrm{kWh}$. According to the hot water outlet temperature, produced by solar water heater system, it can be said that in most hours of the day and night, the outlet temperature is suitable for use for hot water consumption.

Figure 14 shows the comparison of the collector inlet and outlet temperatures for a designed solar water heater system. It is clear that the outlet temperature of collector is acceptable for the supply of hot water.

In the following, we will review the results for a cold day of the year, January 4. Figure 15 shows the generated thermal energy by the solar water heater system for this day of the year. It can be seen that the designed system produces about $10276 \mathrm{~kJ}$. According to previous statements, it is concluded that on cold days of the year, the solar water heater system needs an auxiliary heat source to supply the hot water. Also, the highest thermal energy on this day is obtained at 11 o'clock, which is equal to $1897 / 53 \mathrm{~kJ} / \mathrm{h}$.

It can be concluded that the system designed in this research is able to provide $75 \%$ of the hot water consumption needs. If we use an auxiliary heat source along with this system, all the hot water consumption needs of the building can be met during the year. In this case, we will save as much as $2373 / 3 \mathrm{kWh}$ energy from fossil energy sources. This energy saving will reduce the economic and social costs of the household at the micro level and the whole community at the 
TABLE 1: Data to calculate the amount of heat required to supply the hot water consumption.

\begin{tabular}{lccc}
\hline Parameter & Value & Parameter & Value \\
\hline Specific water gravity at constant pressure & $4.18 \mathrm{~kJ} / \mathrm{kg} . \mathrm{K}$ & Minimum temperature of inlet water to solar water heater & $15.5^{\circ} \mathrm{C}$ \\
The actual amount of hot power consumed per day & 240 lit & Maximum temperature of outlet water from solar water heater & $60^{\circ} \mathrm{C}$ \\
\hline
\end{tabular}

TABLE 2: Specifications of the components of solar water heater system.

\begin{tabular}{lccc}
\hline Parameter & Value & Parameter & Value \\
\hline Collector area & $3 / 8 \mathrm{~m}^{2}$ & IAM & $0 / 09$ \\
Volumetric flow rate of whole system & $0 / 05 \mathrm{~kg} / \mathrm{s}$ & Tank volume & $0 / 77 \mathrm{~m}^{3}$ \\
Operating fluid & Water & Fluid inlet temperature $(\mathrm{Fr})$ & $15 / 5^{\circ} \mathrm{C}$ \\
Collector slope angle & 35 & Fluid output temperature & $60^{\circ} \mathrm{C}$ \\
Azimuth angle of collector & 180 & Pump power & $30 \mathrm{~W}$ \\
$F_{R}(\tau \alpha)$ & $84 / 0$ & Pump efficiency & $0 / 85$ \\
$F_{R} U_{L}$ & $6 / 8 \mathrm{~W} / \mathrm{m}^{2} . \mathrm{C}$ & & \\
\hline
\end{tabular}

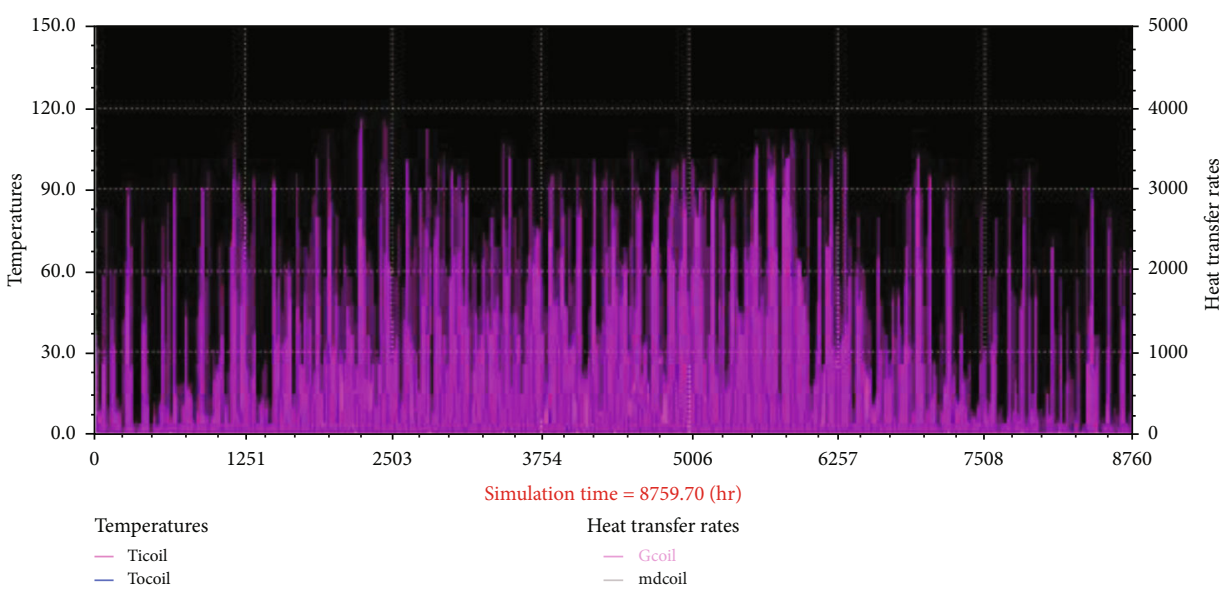

Figure 9: Thermal energy generated by the solar water heater system.

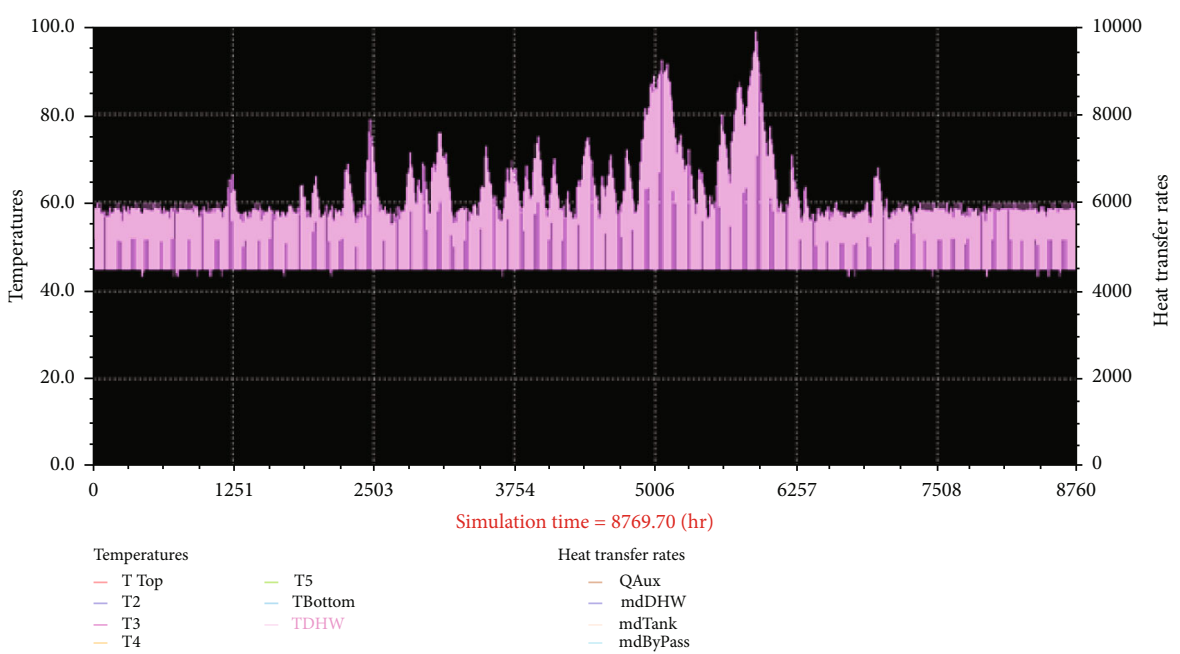

Figure 10: The hot power temperature produced by the solar water heater system. 


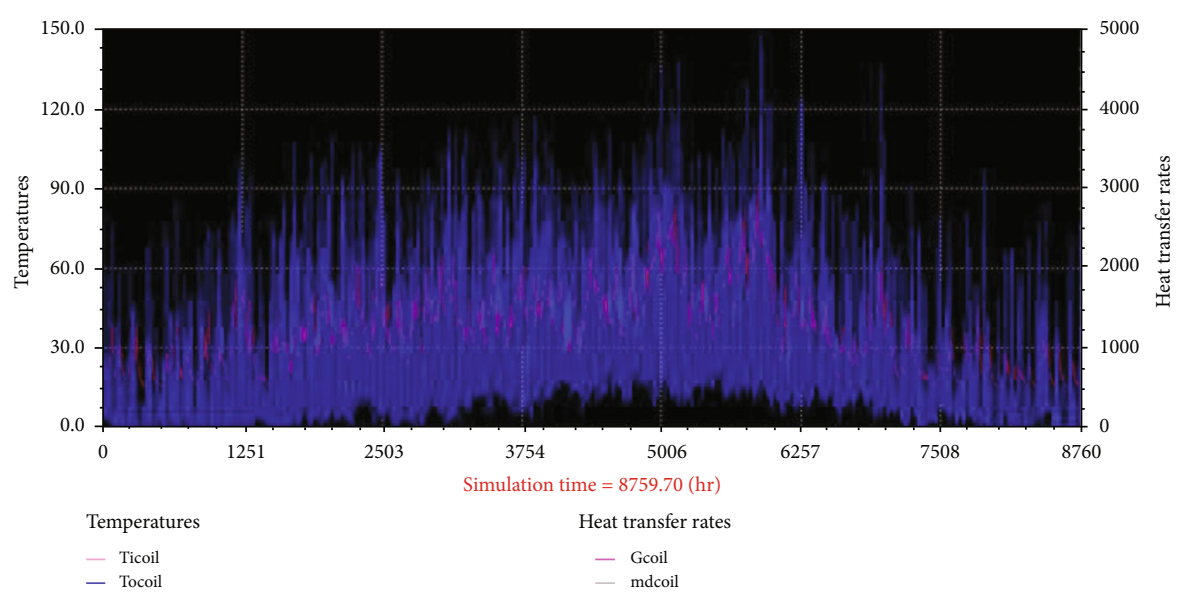

FIGURE 11: Comparison of inlet and outlet temperature of solar collector heating system (red input temperature, blue outlet temperature).

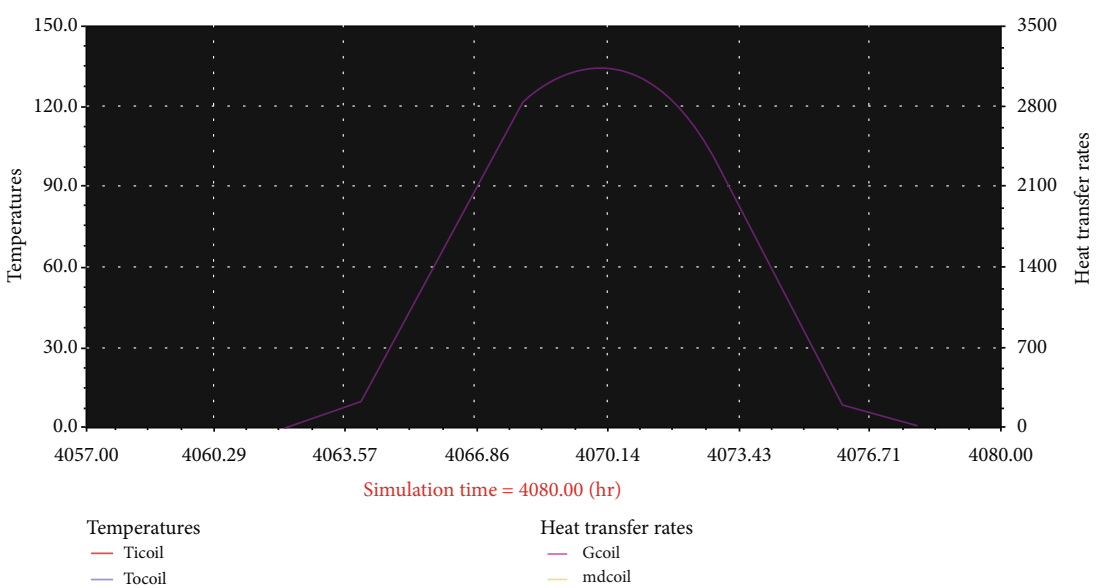

Figure 12: Thermal energy produced by the solar water heater system on June 18 .

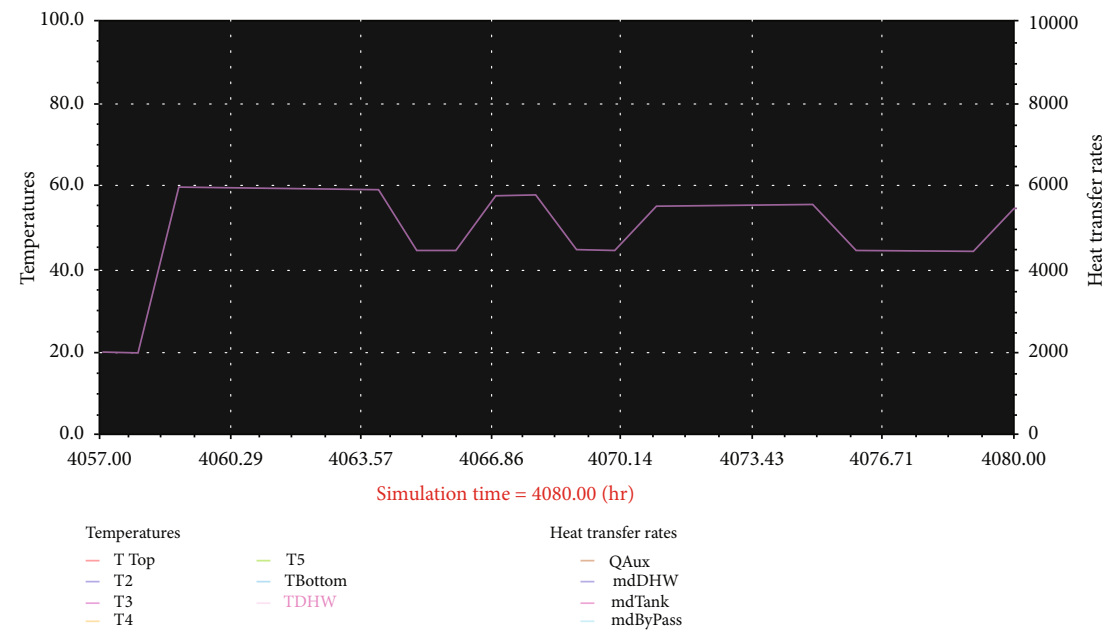

Figure 13: Hot water temperature produced by the solar water heater system on June 18. 


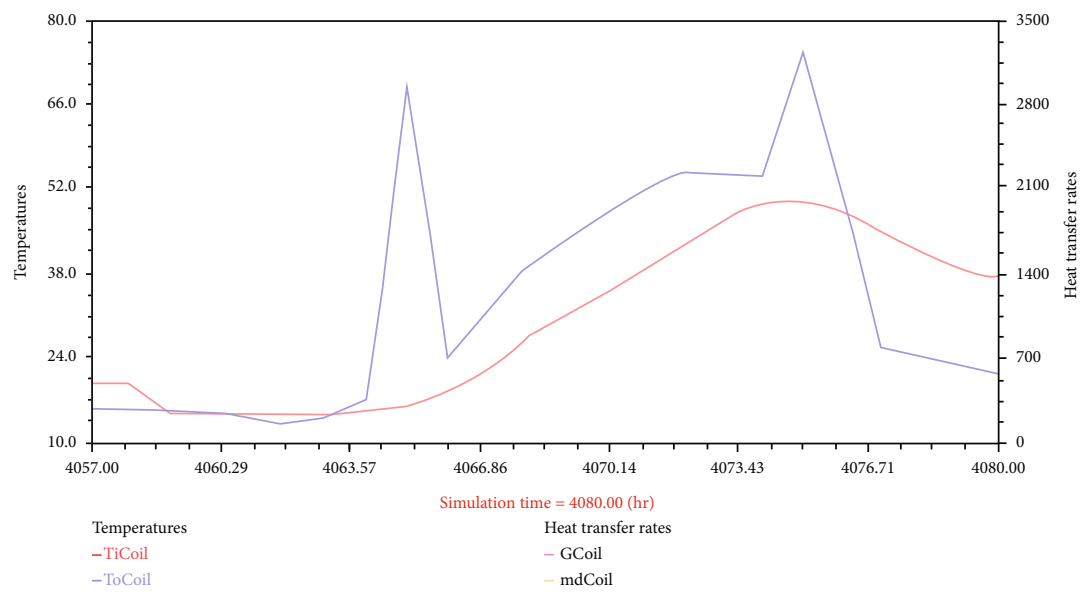

FIGURE 14: Comparison of collector inlet and outlet temperature in solar water heater system.

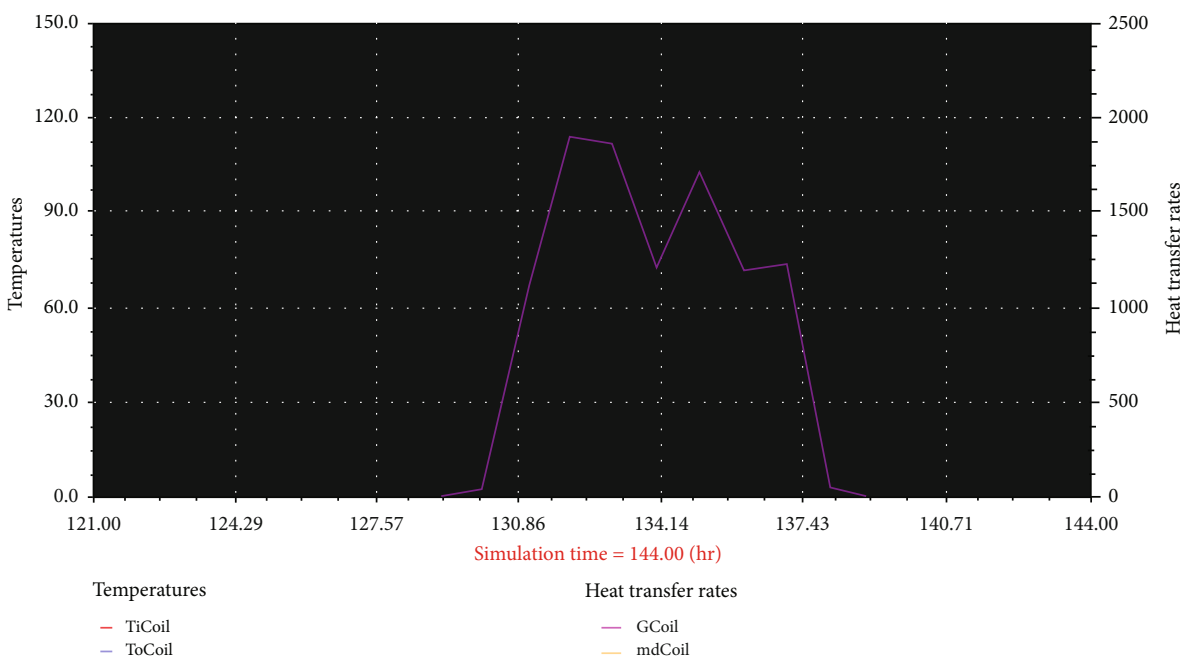

FIgURE 15: Thermal energy generated by the solar water heater system on January 4.

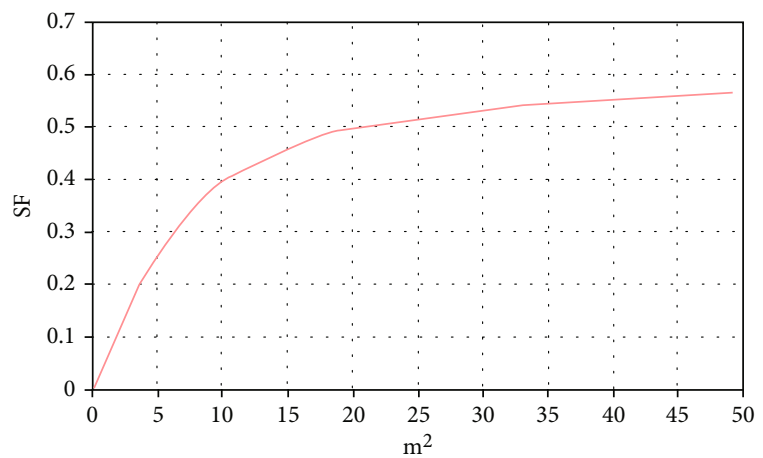

FIGURE 16: Solar fraction rate according to the area of the collector.

macro level, which will discuss in the next section. Now, to consider the efficiency of the system, after calculating the $\mathrm{SF}_{1}$ for the solar system, we increase the number of collectors and draw the SF diagram in terms of the collector area, which is shown in Figure 16.

$$
\mathrm{SF}=1-\frac{Q_{\text {Solar }}-Q_{\text {Pupm }}}{Q_{\text {non-Solar }}} .
$$

In this study, the value of SF based on the above equation is equal to 0.19 . As the number of collectors increases, the efficiency of the system decreases due to the high losses of collectors, which should be considered.

3.1. Environmental Analysis. The production of polluting gases causes damage to the ecosystem and the health of the community. Expenses should be made in the country's economy to compensate for these damages. The total amount of money is spent to compensate for the damage to the ecosystem, health, and well-being of the people of the society, etc., known as social costs that are caused by the emission of polluting gases and greenhouse gases. The highest social costs of the energy sector are related to greenhouse gas emissions $\left(\mathrm{SO}_{2}, \mathrm{NO}_{\mathrm{x}}\right.$, and $\left.\mathrm{CO}_{2}\right)$. Social costs of consuming fossil energy carriers for various pollutants in the country are stated in the annual energy balance sheet. The use of solar water heaters 
TABLE 3: The amount of reduction in pollutant gases through the use of solar water heater system.

\begin{tabular}{lcc}
\hline Polluting gas & $\begin{array}{c}\text { Dissemination value } \\
\text { per kWh }\end{array}$ & $\begin{array}{c}\text { Reduction by solar water } \\
\text { heater (kg/year) }\end{array}$ \\
\hline $\mathrm{CO}_{2}$ & $678 / 24$ & $2302 / 62$ \\
$\mathrm{SO}_{2}$ & $2 / 67$ & $9 / 06$ \\
$\mathrm{NO}_{x}$ & $2 / 24$ & $7 / 6$ \\
Total & $683 / 15$ & $2319 / 28$ \\
\hline
\end{tabular}

will reduce greenhouse gas emissions and reduce social costs due to the reduced use of fossil energy. Table 3 shows the emission of pollutants and greenhouse gases for every $\mathrm{kWh}$ of electricity. In the country, among polluting gases, $\mathrm{CO}_{2}$ gas with an emission index of 67.248 grams per kilowatt hour, $\mathrm{NO}_{\mathrm{x}}$ with an emission index of $2.67 \mathrm{gr} / \mathrm{kWh}$, and $\mathrm{SO}_{2}$ with an emission index of $2.24 \mathrm{gr} / \mathrm{kWh}$ are the most pollutants gases. Considering the emission rate of polluting gases per kilowatt hour and according to the data obtained by saving energy through the use of solar water heating system, it will be possible to calculate the amount of reduction of polluting gases. Table 3 shows the amount of reduction in pollutant gases through the use of solar water heater system.

\section{Conclusion}

Due to the reduction of nonrenewable fossil resources and replacement of renewable energy sources, solar energy does not contain pollution and widely available in all parts of the world, especially in warm regions. Due to the fact that the highest energy consumption in a building is related to space heating and water consumption. Therefore, in this research, the use of solar energy for building heating has been considered. As can be mentioned, the most important results of the following:

(i) Annually, $4526 / 24 \mathrm{kWh}$ heat is required to supply the hot a study residential building residential building. If $75 \%$ of this energy is supplied by the solar system, the total amount of energy from the solar water heater system for a family of four people will be equal to $3395 \mathrm{kWh}$

(ii) The system designed in this research is able to provide $75 \%$ of the hot water consumption needs. If we use an auxiliary heat source besides this system, we can provide all the hot water needs of the building during the year. In this case, we will have as much as $2373 / 3 \mathrm{kWh}$ energy savings from fossil energy sources

\section{Nomenclature}

$M$ : the actual amount of hot water consumed (day/liters)

CP: specific heat, J. kg-1. K-1

$T$ : $\quad$ Water temperatures $(\mathrm{K})$

SF: Solar fraction.

\section{Data Availability}

Data will be made available on demand.

\section{Conflicts of Interest}

The authors declare that they have no conflicts of interest.

\section{Acknowledgments}

The author would like to thank Islamic Azad University (Germi Branch), Iran.

\section{References}

[1] A. Sieminski, "International energy outlook," Energy information administration (EIA), vol. 18, 2014.

[2] R. K. Smith, "Evolving coal-fired power plant carbon dioxide emission rate intensities on U.S. electricity operating systems," Journal of Modern Power Systems and Clean Energy, vol. 6, no. 6, pp. 1103-1112, 2018.

[3] Z. M. Chen and G. Q. Chen, "An overview of energy consumption of the globalized world economy," Energy Policy, vol. 39, no. 10, pp. 5920-5928, 2011.

[4] S. Ahmad and R. M. Tahar, "Selection of renewable energy sources for sustainable development of electricity generation system using analytic hierarchy process: a case of Malaysia," Renewable Energy, vol. 63, pp. 458-466, 2014.

[5] A. Demirbas, "Potential applications of renewable energy sources, biomass combustion problems in boiler power systems and combustion related environmental issues," Progress in Energy and Combustion Science, vol. 31, no. 2, pp. 171192, 2005.

[6] D. Gielen, F. Boshell, D. Saygin, M. D. Bazilian, N. Wagner, and R. Gorini, "The role of renewable energy in the global energy transformation," Energy Strategy Reviews, vol. 24, pp. 38-50, 2019.

[7] R. Alayi and H. Rouhi, "Techno-economic analysis of electrical energy generation from urban waste in Hamadan, Iran," International Journal of Design \& Nature and Ecodynamics, vol. 15, no. 3, pp. 337-341, 2020.

[8] A. Qazi, F. Hussain, N. A. Rahim et al., "Towards sustainable energy: a systematic review of renewable energy sources, technologies, and public opinions," IEEE Access, vol. 7, pp. 6383763851, 2019.

[9] G. Hartfield, J. Blunden, and D. S. Arndt, "State of the climate in 2017," Bulletin of the American Meteorological Society, vol. 99, no. 8, pp. Si-S310, 2018.

[10] R. Alayi, A. Kasaeian, and F. Atabi, "Optical modeling and optimization of parabolic trough concentration photovoltaic/thermal system," Environmental Progress \& Sustainable Energy, vol. 39, no. 2, article e13303, 2019.

[11] R. Alayi, R. Kumar, S. R. Seydnouri, M. H. Ahmadi, and A. Issakhov, "Energy, environment and economic analyses of a parabolic trough concentrating photovoltaic/thermal system," International Journal of Low-Carbon Technologies, vol. 16, no. 2, pp. 570-576, 2020.

[12] R. Alayi, M. H. Ahmadi, A. R. Visei, S. Sharma, and A. Najafi, "Technical and environmental analysis of photovoltaic and solar water heater cogeneration system: a case study of Saveh City," International Journal of Low-Carbon Technologies, vol. 16, no. 2, pp. 447-453, 2020.

[13] P. Chen, X. Xiao, and X. Wang, "Interval optimal power flow applied to distribution networks under uncertainty of loads and renewable resources," Journal of Modern Power Systems and Clean Energy, vol. 7, no. 1, pp. 139-150, 2019. 
[14] S. Kalogirou, "Thermal performance, economic and environmental life cycle analysis of thermosiphon solar water heaters," Solar Energy, vol. 83, no. 1, pp. 39-48, 2009.

[15] H. Li, J. Zhao, M. Li et al., "Determining the economic design radiation for a solar heating system through uncertainty analysis," Solar Energy, vol. 195, pp. 54-63, 2020.

[16] C. J. Koroneos and E. A. Nanaki, "Life cycle environmental impact assessment of a solar water heater," Journal of Cleaner Production, vol. 37, pp. 154-161, 2012.

[17] K. Tanha, A. S. Fung, and R. Kumar, "Performance of two domestic solar water heaters with drain water heat recovery units: simulation and experimental investigation," Applied Thermal Engineering, vol. 90, pp. 444-459, 2015.

[18] J. Shi, W. Su, M. Zhu et al., "Solar water heating system integrated design in high-rise apartment in China," Energy and Buildings, vol. 58, pp. 19-26, 2013.

[19] C. Dharuman, J. H. Arakeri, and K. Srinivasan, "Performance evaluation of an integrated solar water heater as an option for building energy conservation," Energy and Buildings, vol. 38, no. 3, pp. 214-219, 2006.

[20] Y. Fan, X. Zhao, J. Li et al., "Economic and environmental analysis of a novel rural house heating and cooling system using a solar-assisted vapour injection heat pump," Applied Energy, vol. 275, p. 115323, 2020.

[21] Y. Cao, L. W. W. Mihardjo, and T. Parikhani, “Thermal performance, parametric analysis, and multi-objective optimization of a direct-expansion solar-assisted heat pump water heater using NSGA-II and decision makings," Applied Thermal Engineering, vol. 181, p. 115892, 2020.

[22] T. T. Chow, K. F. Fong, A. L. S. Chan, and Z. Lin, "Potential application of a centralized solar water-heating system for a high- rise residential building in Hong Kong," Applied Energy, vol. 83, no. 1, pp. 42-54, 2006.

[23] R. Alayi and F. Jahanbin, "Generation management analysis of a stand-alone photovoltaic system with battery," Renewable Energy Research and Application, vol. 1, no. 2, pp. 205-209, 2019.

[24] C. Su, H. Madani, and B. Palm, "Heating solutions for residential buildings in China: current status and future outlook," Energy Conversion and Management, vol. 177, pp. 493-510, 2018.

[25] M. Souliotis, G. Panaras, P. A. Fokaides, S. Papaefthimiou, and S. A. Kalogirou, "Solar water heating for social housing: energy analysis and life cycle assessment," Energy and Buildings, vol. 169, pp. 157-171, 2018.

[26] M. Fani and A. Sadreddin, "Solar assisted CCHP system, energetic, economic and environmental analysis, case study: educational office buildings," Energy and Buildings, vol. 136, pp. 100-109, 2017.

[27] L. Altoé, D. Oliveira Filho, J. C. Carlo, P. M. B. Monteiro, and I. T. A. Martins, "An analysis of the economic viability and greenhouse gas emissions reductions resulting from the use of solar water heaters in a typical Brazilian dwelling," Latin American Journal of Energy Research, vol. 4, no. 2, pp. 1-10, 2017.

[28] M. S. Hossain, A. K. Pandey, M. A. Tunio, J. Selvaraj, K. E. Hoque, and N. A. Rahim, "Thermal and economic analysis of low-cost modified flat-plate solar water heater with parallel two-side serpentine flow," Journal of Thermal Analysis and Calorimetry, vol. 123, no. 1, pp. 793-806, 2016.
[29] A. Şerban, N. Bărbuță-Mişu, N. Ciucescu, S. Paraschiv, and S. Paraschiv, "Economic and environmental analysis of investing in solar water heating systems," Sustainability, vol. 8, no. 12, p. 1286, 2016.

[30] S. D. Fertahi, T. Bouhal, F. Gargab, A. Jamil, T. Kousksou, and A. Benbassou, "Design and thermal performance optimization of a forced collective solar hot water production system in Morocco for energy saving in residential buildings," Solar Energy, vol. 160, pp. 260-274, 2018.

[31] O. Ayadi and S. Al-Dahidi, "Comparison of solar thermal and solar electric space heating and cooling systems for buildings in different climatic regions," Solar Energy, vol. 188, pp. 545560, 2019.

[32] R. Alayi, A. Kasaeian, and F. Atabi, "Thermal analysis of parabolic trough concentration photovoltaic/thermal system for using in buildings," Environmental Progress \& Sustainable Energy, vol. 38, no. 6, p. 13220, 2019.

[33] R. G. Stein, C. Stein, M. Buckley, and M. Greenpartners, Handbook of energy use for building construction (no. DOE/CS/20220-1), R. G. Stein, Ed., New York City, 1980. 